\title{
Molecular tectonics: hierarchical organization of heterobimetallic coordination networks into heterotrimetallic core-shell crystals
}

Received 00th January 20xx, Accepted 00th January 20xx

DOI: $10.1039 / \times 0 \times x 00000 x$

\author{
Fan Zhang, Cyril R. R. Adolf, Nicolas Zigon, Sylvie Ferlay, ${ }^{*}$ Nathalie Kyritsakas, \\ Mir Wais Hosseini*
}

www.rsc.org/

Combinations of a neutral Pt(II) organometallic tecton bearing two triphenylphosphine and two 3-ethynylpyridyl coordinating moieties in trans positions with $\mathrm{MX}_{2}$ complexes $(\mathrm{M}=\mathrm{Co}$ (II) and $\mathrm{X}=$ $\mathrm{Cl}^{-}$or $\mathrm{Br}^{-}$and $\mathrm{M}=\mathrm{Zn}(\mathrm{II})$ and $\mathrm{X}=\mathrm{Cl}^{-}$) lead to the formation of isostructural 1D heterobimetallic coordination compounds. By 3D epitaxial growth processes, using coordination bonding, heterotrimetallic core-shell crystals are generated by growth of crystalline layers on seed crystals.

For the development of new molecular materials and devices, mastering of molecular organization in the solid state is of prime importance. Hierarchical construction of solid-state matter composed of several crystalline domains with continuity of short- and long-range orders is challenging. The generation of core-shell crystals is a pertinent example of such hierarchical construction. ${ }^{1}$ Core-shell crystals are formed between different isostructural and almost isometric crystalline organizations by 3D epitaxial growth of crystalline layers on seed crystals. This construction strategy is based on principles developed by the molecular tectonics approach. ${ }^{2}$ The latter deals with the formation of molecular networks ${ }^{3}$ leading to extended crystalline architectures displaying translational symmetry. The formation of periodic assemblies results from mutual interconnection of complementary tectons, ${ }^{4}$ by self-assembly processes.

For the generation of core-shell crystals by 3D epitaxial growth, isostructurality and close unit cell metrics between crystals are the two prerequisites. So far, only few molecular core-shell crystals have been reported. Most of the documented examples are mainly based on $\mathrm{H}$-bonded systems.5,6 However, rare examples based on discrete coordination complexes ${ }^{7}$ or coordination polymers ${ }^{8}$ have been also reported. Examples of epitaxial growth using nanoscopic systems such as nanoparticles or films have been also described. ${ }^{9}$

Here we report on the synthesis of the organometallic tecton 1 and on the formation of crystalline 1D heterobimetallic coordination compounds in the presence of $\mathrm{MX}_{2}(\mathrm{M}=\mathrm{Co}(\mathrm{II})$ or $\mathrm{Zn}(\mathrm{II}))$ metallic complexes. Furthermore, based on coordination bonding, we describe the generation of core-shell crystals by 3D epitaxial growth of crystalline layers on preformed seed crystals.

Dealing with the formation of core-shell crystals, we ${ }^{1,5}$ and others ${ }^{6 a-c}$ have previously designed $\mathrm{H}$-bonded architectures. One may argue that the formation of core-shell crystals may be due to the use of $\mathrm{H}$-bonding which is rather tolerant both in terms of distance and angle and thus may compensate slight mismatches in metrics of unit cells between isostructural crystals. In order to further explore this issue, we have designed the tecton 1 (Figure 1) and investigated the formation of isostructural and almost isometric crystals upon its combinations with different neutral metal halide complexes $\mathrm{MX}_{2}\left(\mathrm{M}=\mathrm{Co}(\mathrm{II})\right.$ and $\mathrm{X}=\mathrm{Cl}^{-}$or $\mathrm{Br}^{-}$and $\mathrm{M}=\mathrm{Zn}(\mathrm{II})$ and $\left.\mathrm{X}=\mathrm{Cl}^{-}\right)$. It might be worth mentioning that, to the best of our knowledge, no example of molecular core-shell crystals based on heterobimetallic coordination polymers has been reported.

The design of the organometallic tecton 1 (Figure 1) is inspired by our previous investigation on the analogous tecton 2. The latter, when combined with metallic complexes $(M=$ $\mathrm{Co}(\mathrm{II}), \mathrm{Ni}(\mathrm{II})$ and $\mathrm{Cd}(\mathrm{II})$ and $\mathrm{X}=\mathrm{Cl}^{-}$or $\mathrm{Br}^{-}$) leads to the formation of heterobimetallic 2D grid architectures. ${ }^{10}$

Several neutral $\mathrm{Pt}(\mathrm{II})$ organometallic bis-alkyne complexes have been reported.11 Tecton $\mathbf{2}$, when combined with 1,4diiodotetrafluorobenzene, leads to the formation of halogen bonded 1D compounds. ${ }^{12}$ Compound $\mathbf{2}$ has been also incorporated into films for catalytic coupling reactions. ${ }^{13}$

The tecton $\mathbf{1}$, a positional isomer of $\mathbf{2}$, is based on a $\mathrm{Pt}(\mathrm{II})$ core adopting a square planar geometry and surrounded by two $\mathrm{P}(\mathrm{Ph})_{3}$ ligands and two 3-pyridyl moieties in trans positions. Both compounds $\mathbf{1}$ and $\mathbf{2}$ are rigid tectons. However, 1, owing to free rotation around pyridyl-C bonds, the latter may adopt two distinct syn apolar and anti centric configurations (Figure $1)$. 


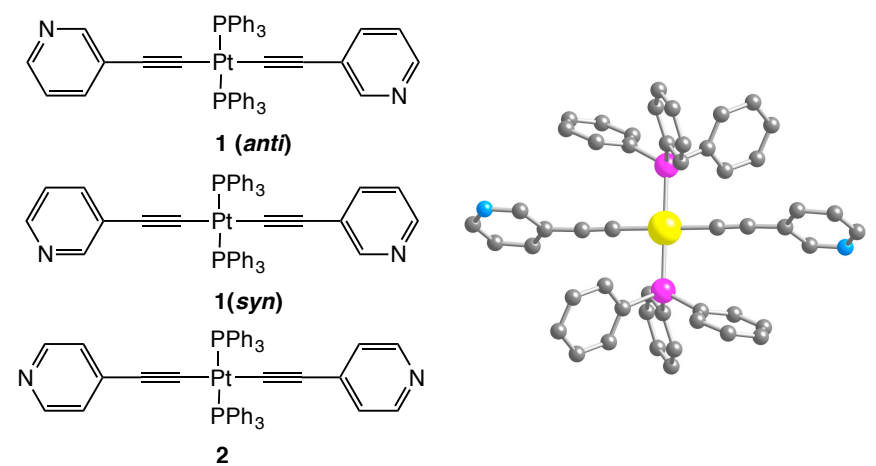

Figure 1: Metallatectons $\left.\mathrm{Pt}(\mathrm{C} \equiv \mathrm{CPy})_{2}\left(\mathrm{PPh}_{3}\right)_{2}\right] \mathbf{1}$ (syn and anti configuration) and $\mathbf{2}$ as well as the crystal structure for $\mathbf{1}$ adopting the anti configuration. Platinum atoms are colored in yellow, nitrogen in blue and phosphosrus in pink. Hydrogen atoms have been omitted for clarity.

Tecton 1 was synthetized in 63\% yield by condensation of cis$\mathrm{PtCl}_{2}\left(\mathrm{PPh}_{3}\right)_{2}$ with 3-ethynylpyridine (see $\left.\mathrm{ESI}\right)$. In addition to common characterization techniques, the solid-state structure of tecton 1 was elucidated by X-ray diffraction on single crystal (XRD) (See ESI). Crystals of 1 have been obtained upon slow diffusion of pentane into a solution of 1 in $\mathrm{C}_{2} \mathrm{H}_{4} \mathrm{Cl}_{2}$. The latter crystallises in the space group $\mathrm{Pbca}$, (see ESI, Crystallographic Table S1). As expected, the Pt(II) cation adopts a deformed square planar geometry (Figure 1 ) with $\mathrm{P}-\mathrm{Pt}-\mathrm{C}$ angle in the $86.79(6)$ - $93.21(6)^{\circ}$ range and P-Pt-P and C-Pt-C angles of $180.0^{\circ}$. The Pt-P and the Pt-C bond lengths of 2.3121(5) $\AA$ and 2.009(2) $\AA$, respectively, are comparable to those previously observed for $2 .{ }^{10} \mathrm{Pt}-\mathrm{C} 14 \equiv \mathrm{C} 15$ and $\mathrm{C} 14 \equiv \mathrm{C} 15-\mathrm{C} 16$ angles are equal to $172.8(2)$ and $172.8(3)^{\circ}$, respectively, indicating a slightly bent nature of the metallatecton.

In order to explore the formation of heterometallic coordination networks, the neutral $\mathrm{Pt}$ (II) based tecton 1 was combined, under self-assembly conditions, with $\mathrm{MX}_{2}(\mathrm{M}=$ $\mathrm{Co}(\mathrm{II})$ and $\mathrm{X}=\mathrm{Cl}^{-}$or $\mathrm{Br}^{-}$and $\mathrm{M}=\mathrm{Zn}(\mathrm{II})$ and $\left.\mathrm{X}=\mathrm{Cl}^{-}\right)$. Upon slow diffusion of 1 dissolved in $\mathrm{C}_{2} \mathrm{H}_{4} \mathrm{Cl}_{2}$ with $\mathrm{MX}_{2}(\mathrm{M}=\mathrm{Co}$ (II) and $\mathrm{X}=$ $\mathrm{Cl}^{-}$or $\mathrm{Br}^{-}$and $\mathrm{M}=\mathrm{Zn}(\mathrm{II})$ and $\mathrm{X}=\mathrm{Cl}^{-}$) salts in $\mathrm{MeOH}$ (see ESI, experimental conditions), several crystals (1- $\mathrm{CoCl}_{2}$ (blue), 1$\mathrm{CoBr}_{2}$ (blue) and $1-\mathrm{ZnCl}_{2}$ (colourless)) were obtained and studied by XRD on single crystals (Figures 2a-c and 5 ).

In all cases, crystals $\left(\left(\mathrm{C}_{7} \mathrm{H}_{4} \mathrm{~N}\right)_{2} \mathrm{Pt}\left(\mathrm{P}\left(\mathrm{C}_{6} \mathrm{H}_{5}\right)_{3}\right)_{2} \mathrm{MX}_{2}, \mathrm{P}-1\right)$ are isomorphous and almost isometric with less than $1.6 \%$ difference in the unit cell parameters (see ESI, Crystallographic Table S1). For all architectures, the M/Pt stoechiometry is $1 / 1$, the tecton $\mathbf{1}$ is in the trans centric configuration (Figure 1) and the metal $M$ adopts a distorted tetrahedral coordination geometry. All crystals are composed of neutral 1D zig-zag (Figure 2d) heterobimetallic $(\mathrm{Pt}, \mathrm{M})$ coordination polymers resulting from the interconnection of consecutive tectons 1 by neutral $M X_{2}$ units (Figure 2). The $M X_{2}$ units, for which the metal $\mathrm{M}$ adopts a distorted tetrahedral geometry, behave as 2connecting $\mathrm{V}$ shape nodes. The $\mathrm{N}-\mathrm{M}-\mathrm{N}$ angle is equal to $95.11(13)^{\circ}, 96.83(9)^{\circ}$ and $97.56(13)^{\circ}$ in $1-\mathrm{ZnCl}_{2}, 1-\mathrm{CoCl}_{2}$ and $1-$ $\mathrm{CoBr}_{2}$ architectures respectively (see Table 1 for characteristic bond distances and angles).
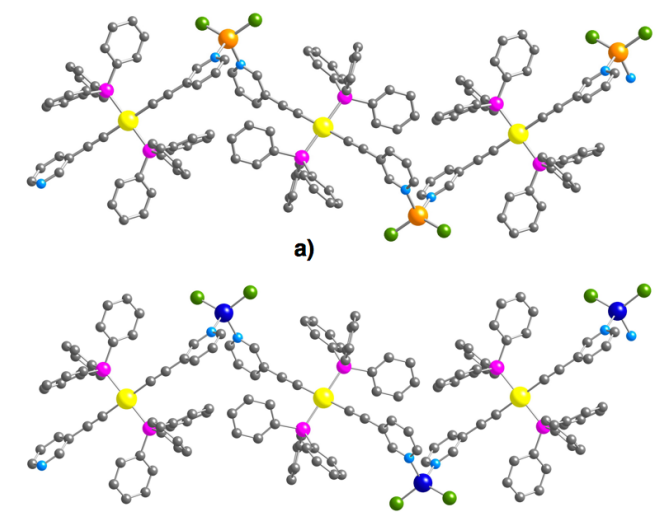

b)

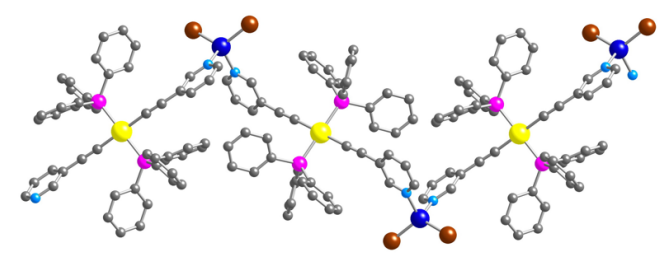

c)

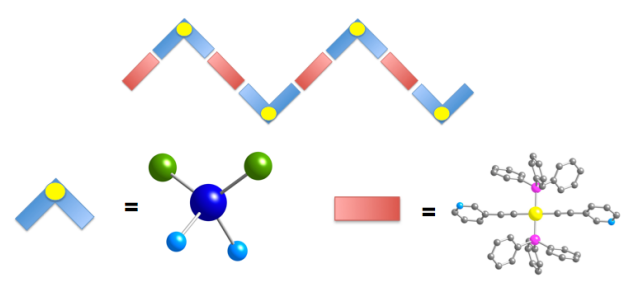

d)

Figure 2: Portions of the 1D zig-zag type compounds formed upon combining the bismonodentate metallatecton 1 with $\mathrm{Co}(\mathrm{II})$ salts: a) $1-\mathrm{ZnCl}_{2}$, b) $1-\mathrm{CoCl}_{2}$ c) $1-\mathrm{CoBr}_{2}$ and d). For sake of clarity, hydrogen atoms and water molecules are omitted. Schematic representation of the connectivity between the metallatecton $\mathbf{1}$ and $\mathrm{MX}_{2}$ leading to a zigzag 1D chain.

\begin{tabular}{|c|c|c|c|}
\hline & $1-\mathrm{ZnCl}_{2}$ & 1- $\mathrm{CoCl}_{2}$ & 1- $\mathrm{CoBr}_{2}$ \\
\hline \multirow[t]{2}{*}{ Pt-C (Å) } & $1.995(4)$ & $1.994(3)$ & $2.005(4)$ \\
\hline & $2.013(4)$ & $2.004(3)$ & $2.007(3)$ \\
\hline \multirow[t]{2}{*}{ Pt-P $(\AA ̊)$} & $2.3127(9)$ & $2.3102(6)$ & $2.3003(8)$ \\
\hline & $2.3003(9)$ & $2.2962(7)$ & $2.3116(8)$ \\
\hline \multirow[t]{2}{*}{ P-Pt-C $\left({ }^{\circ}\right)$} & $86.09(11)$ - & $86.13(8)$ - & $86.17(10)-$ \\
\hline & 93.91(11) & $93.87(8)$ & $93.83(10)$ \\
\hline \multirow[t]{2}{*}{$\mathrm{Pt}-\mathrm{C} \equiv \mathrm{C}\left({ }^{\circ}\right)$} & $176.6(3)$ & $176.4(2)$ & $176.7(3)$ \\
\hline & $178.8(3)$ & $179.0(2)$ & $178.2(3)$ \\
\hline \multirow[t]{2}{*}{$C \equiv C-C\left({ }^{\circ}\right)$} & $174.1(4)$ & $173.6(3)$ & $174.1(4)$ \\
\hline & $176.7(4)$ & $176.8(3)$ & $176.4(4)$ \\
\hline \multirow[t]{2}{*}{$M-X(\AA ̊)$} & $2.2062(12)$ & $2.2188(9)$ & $2.3509(6)$ \\
\hline & $2.2139(12)$ & $2.2275(10)$ & $2.3708(6)$ \\
\hline \multirow[t]{2}{*}{$\mathrm{M}-\mathrm{N}(\AA ̊)$} & $2.058(3)$ & $2.034(2)$ & $2.034(3)$ \\
\hline & $2.076(3)$ & $2.052(2)$ & $2.048(3)$ \\
\hline $\mathrm{N}-\mathrm{M}-\mathrm{N}\left({ }^{\circ}\right)$ & $95.11(13)$ & $96.83(9)$ & $97.56(13)$ \\
\hline \multirow[t]{2}{*}{$\mathrm{N}-\mathrm{M}-\mathrm{X}\left({ }^{\circ}\right)$} & 107.09(10)- & 107.72(7) - & 108.43(9) - \\
\hline & $110.86(9)$ & $111.33(7)$ & $111.65(8)$ \\
\hline $\mathrm{X}-\mathrm{M}-\mathrm{X}\left({ }^{\circ}\right)$ & $122.77(5)$ & $120.36(4)$ & $118.84(3)$ \\
\hline
\end{tabular}

Table 1: Comparison of bond distances and angles for $1-\mathrm{ZnCl}_{2}, 1-\mathrm{CoCl}_{2}$ and 1- $\mathrm{CoBr}_{2}$. 
The chains are packed in a parallel fashion along the $a$ and $b$ axis (figure 3 ).

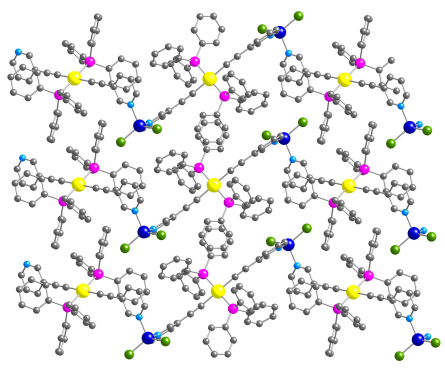

a)

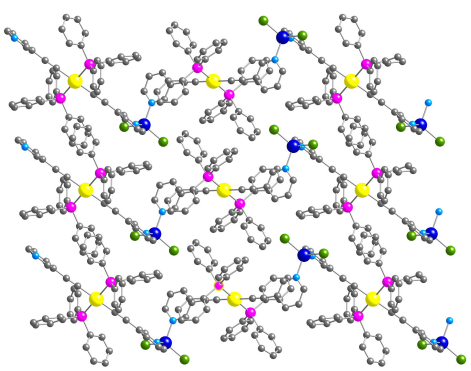

b)

Figure 3: Portions of the packing of the 1-MX $1 \mathrm{D}$ compounds $\left(\mathrm{M}=\mathrm{Co}(\mathrm{II})\right.$ and $\mathrm{X}=\mathrm{Cl}^{-}$or $\mathrm{Br}$ and $\mathrm{M}=\mathrm{Zn}(\mathrm{II})$ and $\left.\mathrm{X}=\mathrm{Cl}^{-}\right)$a) along the $b$ axis and $\mathrm{b}$ ) along the $a$ axis. Owing to the isostructural nature of all three crystals, on the packing of $1-\mathrm{CoCl}_{2}$ is represented. For the sake of clarity hydrogen atoms are omitted.

The purity of all three crystalline materials was established by $X$-Ray diffraction on polycrystalline powders (figure 4). The XRPD study confirmed the isomorphous nature of all three crystals. Indeed, all three powdered compounds $\left(1-\mathrm{ZnCl}_{2}, 1\right.$ $\mathrm{CoCl}_{2}$ and 1- $\mathrm{CoBr}_{2}$ ) display analogous diffraction patterns with a good match with the one simulated using the XRD data for 1$\mathrm{ZnCl}_{2}$. It is worth noting that, although crystals are reproducibly obtained, they are not stable for extended period of time outside the crystallisation solvent system.

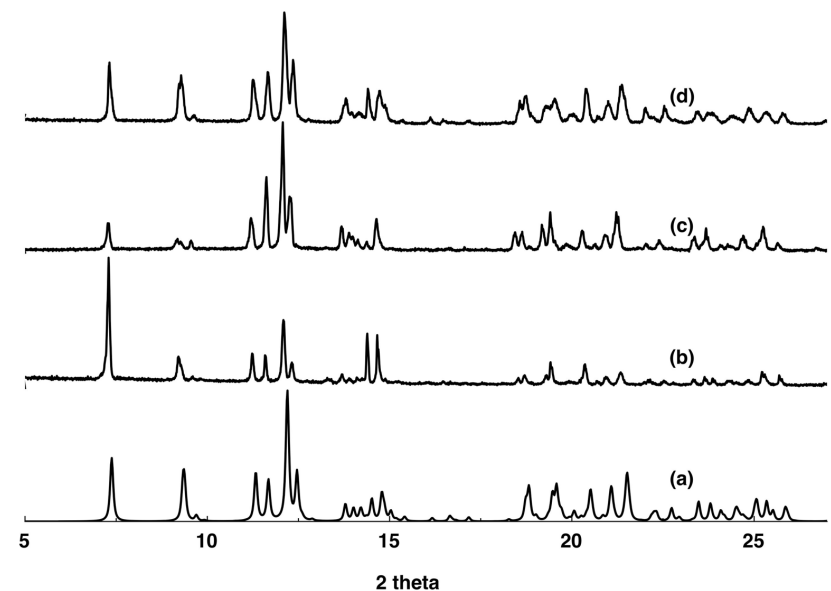

Figure 4: Simulated XRPD pattern for $1-\mathrm{CoCl}_{2}$ (a) and recorded patterns for $1-\mathrm{CoCl}_{2}$ (b) $1-\mathrm{CoBr}_{2}$ (c) and $1-\mathrm{ZnCl}_{2}$ (d) showing the homogeneity of phases and their isostructurality.
Taking advantage of the isostructurality of the three crystalline materials based on tecton 1 and the colour difference i.e. blue for $1-\mathrm{CoX}_{2}$ (Figure $5 \mathrm{a}$ and $\mathrm{b}$ ) and colourless for $1-\mathrm{ZnCl}_{2}$ (Figure $5 \mathrm{c}$ ), the formation of core-shell crystals by $3 \mathrm{D}$ epitaxial growth was explored.

Starting with either $1-\mathrm{CoCl}_{2}$ or $1-\mathrm{CoBr}_{2}$ as blue seed crystals, the epitaxial growth of colourless crystalline layer of $1-\mathrm{ZnCl}_{2}$ leading to 1- $\mathrm{ZnCl}_{2} @ 1-\mathrm{CoBr}_{2}$ (Figure 5d) and 1- $\mathrm{ZnCl}_{2} @ 1-\mathrm{CoCl}_{2}$ (Figure $5 e$ ) core-shell crystals was achieved.

Unfortunately, owing to low quality of the $1-\mathrm{ZnCl}_{2}$ crystals (see ESI, Table S2), It was not possible achieve the reverse process, i.e. growth of crystalline layers of either $1-\mathrm{CoBr}_{2}$ or $1-\mathrm{CoCl}_{2}$ on $1-\mathrm{ZnCl}_{2}$ seed crystal leading to 1- $\mathrm{CoBr}_{2} @ 1-\mathrm{ZnCl}_{2}$ and 1$\mathrm{CoCl}_{2} @ 1-\mathrm{ZnCl}_{2}$.

Both 1- $\mathrm{ZnCl}_{2} @ 1-\mathrm{CoBr}_{2}$ and 1- $\mathrm{ZnCl}_{2} @ 1-\mathrm{CoCl}_{2}$ core-shell crystals were analysed by XRD which revealed that the epitaxial growth takes place with conservation of both short and long range orders leading thus composite single crystals. Indeed, cell parameters of the core-shell crystal are almost identical to those of i) the pure $1-\mathrm{ZnCl}_{2}$, ii) the $1-\mathrm{ZnCl}_{2}$ crystalline zone obtained by cutting the core-shell crystal, iii) the pure $1-\mathrm{CoBr}_{2}$ (or 1- $\mathrm{CoCl}_{2}$ ) crystal, iv) the 1- $\mathrm{CoBr}_{2}$ (or 1- $\mathrm{CoCl}_{2}$ ) crystalline zone obtained by cutting the core-shell crystal (Table 2 ).

\begin{tabular}{|c|c|c|c|}
\hline Compound & $\begin{array}{c}\text { 1-ZnCl } \mathrm{ZnC}_{2} @ \mathrm{CoBr}_{2} \\
\mathrm{CoB}\end{array}$ & $\begin{array}{c}\text { 1- } \mathrm{ZnCl}_{2} \text { (cut from } \\
\text { 1- } \mathrm{ZnCl}_{2} @ \mathbf{1 -} \\
\left.\mathrm{CoBr}_{2}\right)\end{array}$ & $\begin{array}{c}\text { 1- } \mathrm{CoBr}_{2} \text { (cut from } \\
\text { 1- }-\mathrm{ZnCl}_{2} @ \mathbf{1 -} \\
\left.\mathrm{CoBr}_{2}\right)\end{array}$ \\
\hline Crystal system & Triclinic & Triclinic & Triclinic \\
\hline Space group & P-1 & P-1 & P-1 \\
\hline $\mathrm{a}(\AA)$ & 9.58 & 9.56 & 9.57 \\
\hline $\mathrm{b}(\AA)$ & 9.64 & 9.65 & 9.63 \\
\hline $\mathrm{c}(\AA)$ & 24.12 & 24.05 & 24.15 \\
\hline$\alpha(\operatorname{deg})$ & 95.07 & 95.14 & 95.15 \\
\hline$\beta(\operatorname{deg})$ & 91.38 & 91.61 & 91.40 \\
\hline$\gamma(\operatorname{deg})$ & 98.42 & 98.56 & 98.35 \\
\hline $\mathrm{V}\left(\AA^{3}\right)$ & 2191 & 2183 & 2206 \\
\hline Compound & $\begin{array}{c}\text { 1-ZnCl } \mathrm{ZnC}_{2} @- \\
\mathrm{CoCl}_{2}\end{array}$ & 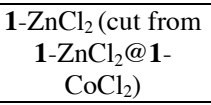 & $\begin{array}{c}\text { 1- } \mathrm{CoCl}_{2} \text { (cut from } \\
\text { 1- } \mathrm{ZnCl}_{2} @ \text { 1- } \\
\mathrm{CoCl}_{2} \text { ) }\end{array}$ \\
\hline Crystal system & Triclinic & Triclinic & Triclinic \\
\hline Space group & P-1 & P-1 & P-1 \\
\hline $\mathrm{a}(\AA)$ & 9.54 & 9.61 & 9.59 \\
\hline $\mathrm{b}(\AA)$ & 9.62 & 9.70 & 9.70 \\
\hline $\mathrm{c}(\AA)$ & 24.07 & 24.17 & 24.17 \\
\hline$\alpha(\operatorname{deg})$ & 95.24 & 95.42 & 95.13 \\
\hline$\beta(\operatorname{deg})$ & 91.78 & 91.42 & 91.49 \\
\hline$\gamma(\operatorname{deg})$ & 98.57 & 98.39 & 98.31 \\
\hline $\mathrm{V}\left(\AA^{3}\right)$ & 2172 & 2217 & 2213 \\
\hline
\end{tabular}

Table 2: Cell parameters recorded at $173 \mathrm{~K}$ for the crystal of crystals 1- $\mathrm{ZnCl}_{2} @ 1-\mathrm{CoBr}_{2}$, and 1- $\mathrm{ZnCl}_{2} @ 1-\mathrm{CoCl}_{2}, 1-\mathrm{ZnCl}_{2}$ (from 1- $\mathrm{ZnCl}_{2} @ 1-\mathrm{CoBr}_{2}$ or 1- $\mathrm{ZnCl}_{2} @ 1-\mathrm{CoCl}_{2}$ ) and 1- $\mathrm{CoBr}_{2}$ or 1- $\mathrm{CoCl}_{2}$ ( from1- $\mathrm{ZnCl}_{2} @ 1-\mathrm{CoBr}_{2}$ or 1- $\mathrm{ZnCl}_{2} @ 1-\mathrm{CoCl}_{2}$ ).

It should be pointed out that the epitaxial growth process leading to core-shell crystals reported here leads to heterotrimetallic ( $\mathrm{Pt}, \mathrm{M} 1$ and $\mathrm{M} 2$ ) hierarchically organised crystalline materials. Indeed, combinations of the $\mathrm{Pt}(\mathrm{II})$ 
organometallic tecton 1 with $\mathrm{MX}_{2}$ metallic nodes lead to the formation of the seed heterobimetallic crystals ( $\mathrm{Pt}$ and $\mathrm{Co}$ ) which, upon epitaxial growth leads to heterotrimetallic architectures (Pt, Co and Zn).

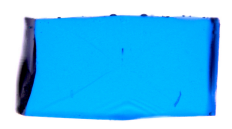

a)

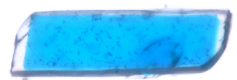

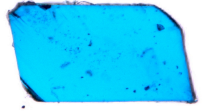

b)

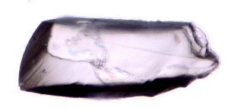

c)
[4] (a) J. D. Wuest, Chem. Commun., 2005, 5830; (b) M. W. Hosseini, Chem. Commun., 2005, 582.

[5] (a) P. Dechambenoit, S. Ferlay, M. W. Hosseini, Cryst. Growth Des., 2005, 5, 2310; (b) E. Brès, S. Ferlay, P. Dechambenoit, H. Leroux, M. W. Hosseini, S. Reyntjens J. Mat. Chem., 2007, 1559; (c) P. Dechambenoit, S. Ferlay, N. Kyritsakas, M. W. Hosseini, Chem. Commun., 2009, 1559; (d) B. K. Olmsted, S. Ferlay, P. Dechambenoit, M. W. Hosseini, M. D. Ward Cryst. Growth Des. 2009, 6, 2841; (e) G. Marinescu, S. Ferlay, N. Kyritsakas and M. W. Hosseini, Chem. Commun., 2013, 11209-11211; (f) C. Adolf, S. Ferlay, N. Kyritsakas, M. W. Hosseini, J. Am. Chem. Soc., 2015, 137, 15390.

Figure 5: Photographs of crystals of: a) $1-\mathrm{CoBr}_{2}$, b) $1-\mathrm{CoCl}_{2}$, c) $1-\mathrm{ZnCl}_{2}$ and $1^{\text {st }}$ generation core-shell crystals of d) 1- $\mathrm{ZnCl}_{2} @ 1-\mathrm{CoBr}_{2}$ and e) 1- $\mathrm{ZnCl}_{2} @ 1-\mathrm{CoCl}_{2}$.

\section{Conclusions}

Hierarchical organization of crystalline materials into core-shell crystals by epitaxial growth is a challenging matter and of current interest. This was achieved by designing the organometallic tecton $\mathbf{1}$ bearing two divergently oriented pyridyl coordinating sites. Combinations of 1 with $\mathrm{MX}_{2}(\mathrm{M}=$ $\mathrm{Co}(\mathrm{II})$ or $\mathrm{Zn}(\mathrm{II})$ and $\mathrm{X}=\mathrm{Cl}^{-}$or $\mathrm{Br}^{-}$) salts behaving as 2-connecting nodes lead to the formation of isostructural and almost isometric crystals composed of neutral 1D coordination compounds. Heterotrimetallic ( $\mathrm{Pt}, \mathrm{Co}$ and $\mathrm{Zn}$ ) core-shell crystals of the type 1- $\mathrm{ZnCl}_{2} @ 1-\mathrm{CoX}_{2}(\mathrm{X}=\mathrm{Cl}$ or $\mathrm{Br})$ have been generated by 3D epitaxial growth processes. Taking advantages of the difference in colour between 1-CoBr 2 (blue) (or a 1- $\mathrm{CoCl}_{2}$ ) and $1-\mathrm{ZnCl}_{2}$ (colourless) crystals, the crystalline growth processes could be visualized. The investigation also demonstrated that coordination bonding may be used for the generation of core-shell crystals.

The interface between the two crystalline zones is currently under investigation using near field microscopy. Welding ${ }^{4 f}$ of isostructural crystals mentioned above in solution and under mild condition is also being investigated.

\section{Acknowledgments}

We thank the University of Strasbourg, the C.N.R.S, the International centre for Frontier Research in Chemistry (icFRC), the Labex CSC (ANR-10-LABX- 0026 CSC) within the Investissement d'Avenir program ANR-10-IDEX-0002-02, the Institut Universitaire de France and the Ministère de l'Enseignement Supérieur et de la Recherche for financial support.

\section{References}

[1] S. Ferlay, M. W. Hosseini, Chem. Commun., 2004, 788.

[2] (a) M. Simard, D. Su and J. D. Wuest, J. Am. Chem. Soc., 1991, 113, 4696; (b) S. Mann, Nature, 1993, 365, 499; (c) M. W. Hosseini, Acc. Chem. Res., 2005, 38, 313.

[3] M. W. Hosseini, CrystEngComm., 2004, 6, 318.
[6] (a) J. C. MacDonald, P. C. Dorrestein, M. M. Pilley, M. M. Foote, J. L. Lundburg, R. W. Henning, A. J. Schultz and J. L. Manson, J. Am. Chem. Soc., 2000, 122, 11692; (b) J. C. Noveron, M. S. Lah, R. E. Del Sesto, A. M. Arif, J. S. Miller and P. J. Stang, J. Am. Chem. Soc., 2002, 124, 6613; (c) T.-J. M. Luo, J. C. MacDonald and G. T. R. Palmore, Chem. Mater., 2004, 16, 4916; (d) K. Sada, K. Inoue, T. Tanaka, A. Epergyes, A. Tanaka, N. Tohnai, A. Matsumoto, M. Miyata, Angew. Chem. Int. Ed. 2005, 44, 7059.

[7] J. W. Steed, A. E. Goeta, J. Lipkowski, D. Swierczynski, V. Panteleon, S. Handad Chem. Commun., 2007, 813.

[8] (a) K. Koh, A. G. Wong-Foy, A. J. Matzger Chem. Commun., 2009, 6162; (b) S. Furukawa, K. Hirai, K. Nakagawa, Y. Takashima, R. Matsuda, T. Tsuruoka, M. Kondo, R. Haruki, D. Tanaka, H. Sakamoto, S. Shimomura, O. Sakata and S. Kitagawa, Angew. Chem., Int. Ed., 2009, 48, 1766; (c) S. Furukawa, K. Hirai, Y. Takashima, K. Nakagawa, M. Kondo, T. Tsuruoka, O. Sakata, S. Kitagawa Chem. Commun. 2009, 5097; (d) Y. Yoo and H.-K. Jeong, Cryst. Growth Des., 2010, 10, 1283; (e) K. Hirai, S. Furukawa, M. Kondo, H. Uehara, O. Sakata, S. Kitagawa Angew. Chem. Int. Ed. 2011, 50, 8057; (f) K. Hirai, S. Furukawa, M. Kondo, M. Meilikhov, Y. Sakata, O. Sakata, S. Kitagawa Chem. Commun., 2012, 48, 6472; (g) T. Fukushima, S. Horike, H. Kobayashi, M. Tsujimoto, S. Isoda, M. L. Foo, Y. Kubota, M. Takata, and S. Kitagawa J. Am. Chem. Soc., 2012, 134, 13341; (h) K. Hirai, K. Chen, T. Fukushima, S. Horike, M. Kondo, N. Louvain, C. Kim, Y. Sakata, M. Meilikhov, O. Sakata, S. Kitagawa, S. Furukawa Dalton Trans., 2013, 42, 15868; (i) L. Wang, W. Yang, Y. Li, Z. Xie, W. Zhu and Z.-M. Sun, Chem. Commun., 2014, 50, 11653.

[9] (a) L. Catala, D. Brinzei, Y. Prado, A. Gloter, O. Stéphan, G. Rogez and T. Mallah, Angew. Chem., Int. Ed., 2009, 48, 183; (b) S. Yoo, H-K. Jeong, Cryst. Growth Des., 2010, 10, 1283; (c) O. Shekhah, J. Liu, R. A. Fischer Ch. Wöll Chem. Soc. Rev., 2011, 40, 1081; (d) M. F. Dumont, E. S. Knowles, A. Guiet, D. M. Pajerowski, A. Gomez, S. W. Kycia, M. W. Meisel and D. R. Talham, Inorg. Chem., 2011, 50, 4295; (e) D. Bradshaw, A. Garai, J. Huo Chem. Soc. Rev., 2012, 41, 2344; (f) P. A. Szilagyi, M. Lutz, J. Gascon, J. Juan-Alcaniz, J. van Esch, F. Kapteijn, H. Geerlings, B. Dam, R. van de Krol CrystEngComm, 2013, 6003; (g) M. Meilikhov, S. Furukawa, K. Hirai, R. A. Fischer, and S. Kitagawa Angew. Chem. Int. Ed., 2013, 52, 341.

[10] N. Zigon, Nathalie Kyritsakas and Mir Wais Hosseini Dalton Trans., 2015, 44, 14204.

[11] W. Wang, H. B. Yang, Chem. Commun., 2014, 50, 5171.

[12] P. Sgarbossa, R. Bertani, V. D. Noto, M. Piga, G. A. Giffin, G. Terraneo, T. Pilati, P. Metrangolo and G. Resnati, Cryst. Growth Des., 2012, 12, 297.

[13] X. Li, X. Zhao, J. Zhang and Y. Zhao, Chem. Commun., 2013, 49, 10004. 


\section{COMMUNICATION}

\section{Graphical Abstract}

Core-shell heterotrimetallic crystals are generated by 3D epitaxial growth using isostructural and almost isometric crystals based on an organometallic tecton and $\mathrm{MX}_{2}$ complexes.

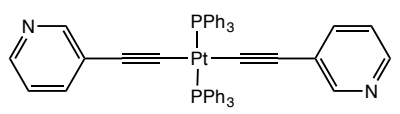

1) $M 1 X_{2}$ 2) $\mathrm{M} 2 X_{2}$ 